\title{
PATHOLOGIE
}

PATHOLOGY

\section{Ròle de La peste poncine Classique SOUS SA FORME SUB-CLINIQUE OU CHRONIQUE DANS LES TROUBLES DE LA REPRODUCTION SUR LE TERRAIN}

\author{
J. M. AYNAUD, C. RIGAUD* et Y. LE TURDU** \\ Laboratoire de Pathologie porcine, I. N. R. A., \\ 78850 Thiverval Grignon \\ * Directeur du Laboratoire des Services vétérinaires des Vosges \\ 88021 Épinal \\ ** Directeur du Laboratoire des Sevvices vétérinaires des Côtes-du-Nord \\ 22440 Saint Brieuc

\section{RÉSUMÉ}

Sur 14 élevages subissant des troubles de la reproduction (stérilité, momification, avortements, mortinatalité) et du retard dans la croissance, nous avons identifié dans I 2 d'entre eux des foyers de peste porcine sub-clinique ou chronique à l'aide de l'isolement du virus mais surtout à l'aide de la mise en évidence des anticorps neutralisants.

Les souches de virus responsables sont peu pathogènes. Leur virulence se manifeste exclusivement sur le foetus et le nouveau-né. Sur le plan antigénique, dans $50 \mathrm{p}$. roo des cas les souches ont été caractérisées comme des variantes sérologiques du virus. Elles présentent un faible pouvoir immunigène et en culture cellulaire leur multiplication est très lente, associée à une immunofluorescence faible et tardive.

\author{
SUMMARY \\ ROLE OF CLASSICAL SUB-CLINICAI, OR CHRONIC \\ SWINE FEVER IN REPRODUCTIVE DISORDERS
}

In 12 out of $\mathrm{I}_{4}$ breeding farms in which economic losses occur due to reproductive disorders (infertility, abortions, mummu fications and stillbirths) or to delayed piglet growth, we have identified subclinical or chronic swine fever by means of virus isolation and especially by means of seroneutralization tests performed in tissue culture. 
Swine fever virus strains isolated in these atypical cases are virulent only for the fotus and the newborn piglet. In $50 \mathrm{p}$. Ioo of these positive cases, seroneutralization tests showed that isolated swine fever virus strains were characterized as serological variants.

These strains are poorly immunogenic. In tissue culture, viral growth is slow and limited, infectivity is reduced and specific immunofluorescence is low and delayed.

\title{
INNOCUITÉ VIS-A-VIS DES TRUIES EN GESTATION \\ DE LA SOUCHE « THIVERVAL " DU VIRUS DE LA PESTE PORCINe CLAssigue
}

\author{
M. LAUNAIS, J. M. AYNAUd, G. CORTHIER et H. LAUDE \\ Laboratoire de Pathologie porcine, I. N.R. A., \\ 78350 Thiverval Grignon \\ Laboratoive C. O. G. L. A., \\ B. P. 126, 33501 Libourne
}

\section{RÉSUMÉ}

Isolée en culture cellulaire à basse température, la souche "Thiverval " est un clone possédant les caractères in vitro "froid " et "fragile ". Vis-à-vis du Porc, cette souche a perdu son pouvoir pathogène, mais a conservé son pouvoir immunigène. Dans la perspective de l'utilisation sans sérum de ce nouveau type de vaccin vivant dans la prophylaxie médicale de la peste porcine, nous avons précisé son innocuité vis-à-vis de l'embryon.

Innoculée à to truies au $2^{\mathbf{e}}$ mois ou au $3^{\mathbf{e}}$ mois de la gestation, la souche "Thiverval " n'a aucune influence défavorable ni sur le déroulement de la gestation, ni sur la qualité des portées obtenues. Les Ioz porcelets nés de ces truies ont eu une croissance normale et se sont révélés parfaitement sensibles à la vaccination ou à l'épreuve virulente pratiquée à l'âge de 3 mois. Ce qui suggère l'absence d'immunité active induite in utero.

Les résultats obtenus suggèrent que la souche "Thiverval " est dépourvue de pouvoir pathogène résiduel.

\section{SUMMARY}

\section{INNOCUITY FOR PREGNANT SOWS OF THE "THIVERVAL " STRAIN FROM CLASSICAI SWINE FEVER VIRUS}

Isolated in tissue culture at low temperature, the "Thiverval " strain is a clone having the in vitro properties of being " cold " and "fragile ". This strain is attenuated for pigs and has good immunogenic properties. In view of its use as a new live vaccine in swine fever medical prophylaxis, we studied its innocuity for foetuses. 